DOI 10.18551/rjoas.2019-08.11

\title{
SETTLEMENT OF THE COMMUNITY'S RESIDENTIAL LAND CONFLICTS
}

\author{
Nafisah Laila*, Muhsin Ahmad \\ Faculty of Industrial Engineering, Universitas Pembangunan Nasional, Indonesia
}

Siswanti Yuni

Faculty of Economy, Universitas Pembangunan Nasional "Veteran" Yogyakarta, Indonesia

\author{
*E-mail: ahmad.muhsin@upnyk.ac.id \\ ORCID: 0000-0003-2457-268x
}

\begin{abstract}
A total of 37 families affected by the earthquake on 27 May 2016 inhabits an area that is the former Winongo Station in Glondong Tirtonirmolo Hamlet, Kasihan, Bantul, Yogyakarta. The great earthquake had devastated houses and claimed 5000 lives. Then, some of those losing their homes inhabit the land owned by the Yogyakarta Palace. Unfortunately, years afterwards, problems arise as to their future destiny. They are anxious and worried if one day the Palace demands that they abandon the land as they do not know where to move. On top of that, there are these individuals persons claiming themselves as descendants of the King of Yogyakarta and legitimate owners of the land, and persuading the community to pay a sum of money to get permits, who were later revealed to be a fraud. Based on those problems, this research aims to seek certainty as to the status of residential land and answer to the community's problems on how to obtain a permit from the Palace of Yogyakarta. In Yogyakarta, land issues are unique issues because they involve many parties in charge of land management and administration, namely the Regional Government; the national land agency, BPN; and Palace of Yogyakarta. Complexity of the problems facing citizens may potentially results in conflicts, making it necessary to take into account perspectives of various parties. This research used the SWOT analysis to determine the position, weaknesses, strengths, and opportunities that are expected to contribute to conflict settlement. Findings of this research indicate that in order to obtain permission to occupy Sultan Ground, residents must submit an application to the Palace of Yogyakarta's Panitikismo section (the section in charge of land affairs) with the regional government's prior approval enclosed with their identity and a letter of recommendation issued by the Village, Sub-district, and BPN. Afterwards, Surat Kekancingan will be issued once the documents submitted are deemed meeting the prescribed requirements, followed by a survey. This Surat Kekancingan constitutes permission to use Sultan Ground. It is then re-registered with BPN. As a great number of residents inhabit this area, it requires teamwork or a communitybased scheme in order to carry out the whole process and maintain security chaired by the Hamlet administrator or board.
\end{abstract}

\section{KEY WORDS}

Surat Kekancingan, Sultan Ground, community, public service.

The Netherlands used to invade Indonesia and in 1755 both countries entered into the Gianti treaty, which concerns the handover of Mataram Kingdom's land to Prince Mangkubumi, marking the establishment of the Province of Yogyakarta. Later, this land is known as Sultan Ground. During the Dutch colonization, the population was comprised of three groups, they were the European people, foreign Eastern people, and indigenous people. Customary law applied to indigenous people while western law applied to the European people and foreign Eastern people. As Mataram Kingdom's land lain in the territory of the indigenous people, it was managed according to the customary law.

In 1945 Indonesia gain its independence and the Province of the Special Region of Yogyakarta was later established in accordance with the Law Number 3 of 1950 and granted 
autonomy, which includes land management. The Law Number 13 of 2012 concerning the Privileges of the Special Region of Yogyakarta sets out special features, i.e. the authority to govern itself, culture, spatial planning, and land affairs. People exploiting its land are required to have a permit in the form of Surat Kekancingan issued by the Palace of Yogyakarta's Panitikismo.

The earthquake that hit Bantul District, Yogyakarta on 27 May 2006 had completely destroyed houses and public facilities, causing more than 5,000 fatalities and many losing their relatives and families. After the earthquake, many people whose houses were devastated finally looked for vacant land to occupy and built a temporary shelter. Most of them occupied the land owned by the Palace, known as Sultan Ground, including the land occupied by 37 heads of families along a former railway line in Glondong Tirtonirmolo Hamlet, Kasihan, Bantul, Yogyakarta. They live and open a business here. Most of them are underprivileged and registered in the poverty alleviation program as recipient of the program called PKH (which stands for Program Keluarga Harapan or Dream Family Program).

They feel anxious and worried about their future destiny if one day they are about to abandon the land they are currently inhabiting. They do realize that they have no official permission to live there, not to mention those individuals claiming themselves as royal families and owners of the land demanding that they pay a sum of money in order to live there, even though they know that official permission from the Palace is issued only by its land affairs section called Panitikismo.

Based on those problems, this research aims to examine certainty as to the status of the land inhabited by the community and examine the legally applicable procedures for land use permits in order to obtain Surat Kekancingan and find a link between the regional government, village officials, BPN, and the Palace's Panitikismo as parties in charge of land affairs. This research involved the community with no legal permit inhabiting Sultan Ground in as the research object.

Most Glondong residents came from different areas as they fell victim to earthquakes. Most of them are underpriviledged with a modest house and no permanent job. Moreover, they do not inhabit their own land as the underprivileged cannot afford it. (Mohindra, Narayana, and Haddad, 2010). The underprivileged are very susceptible to health, mental, education, and prosperity issues. (Najman et al., 2018). Teenagers aged 14 to 21 are vulnerable to depression. (Najman et al., 2010). The community's neighborhood contributes to their poverty as well (Schulz et al., 2012). Community empowerment will be more fruitful if it is based on the criteria identified directly from the community (Muhsin, Hapsoro, and Yuni, 2018) in the form of community participation (Loo, 2014). The community development program is carried out through community empowerment (Thomas et al., 2012) in atimely manner by examining their potential (Marcus, Wilkinson, and Marshall, 2002). Participatory Rural Appraisal is among the method adopted to find solutions to community empowerment issues through community engagement in analyzing the current condition and potential based on the principles of community engagement and participation-based implementation (Muhsin, Nafisah, and Siswanti, 2018).

Based on the previous research, Surat Kekancingan issued by the Palace of Yogyakarta's Panitikismo constitutes the legitimate permit to use the Palace's land (Nafisah, Muhsin and Siswanti, 2019). This research intends to help the community gain insights into the procedures for obtaining the permit to use the land they are inhabiting. The significance of the research is to inform the community of the bureaucracy and requirements to meet to obtain a permit to live on Sultan Ground.

\section{METHODS OF RESEARCH}

This research adopted Participatory Rural Appraisal (PRA) with community engagement and participates in the identification of problems and in search of their solutions. The community included not only residents but also stakeholders involved in residential land licensing such as heads of the hamlet or sub-village and neighborhood association. Primary data were collected by conducting interviews and disseminating questionnaires to community 
members and to relevant hamlets with access to higher levels of government. The SWOT analysis was used to identify possible strengths, weaknesses, potentials, and opportunities to help determine certainty as to the ownership status and bureaucracy to obtain a permit for Sultan Ground in Glondong Tirtonirmolo hamlet, Kasihan, Bantul, Yogyakarta. Secondary data were gathered from relevant literature, including laws and other references.

\section{RESULTS AND DISCUSSION}

A map of conflicts were used to determine the relationship among relevant parties. In this research, the problem was the people's concern about the status of the land they are currently inhabiting as they have not obtained official permission to use it. If one day they are required to abandon the land, they have no grounds to stay because they occupy it illegally. On the other hand, they have stayed in the land long enough, i.e. for more tan 13 years, have a family, built a house, and depend their lives on that place.

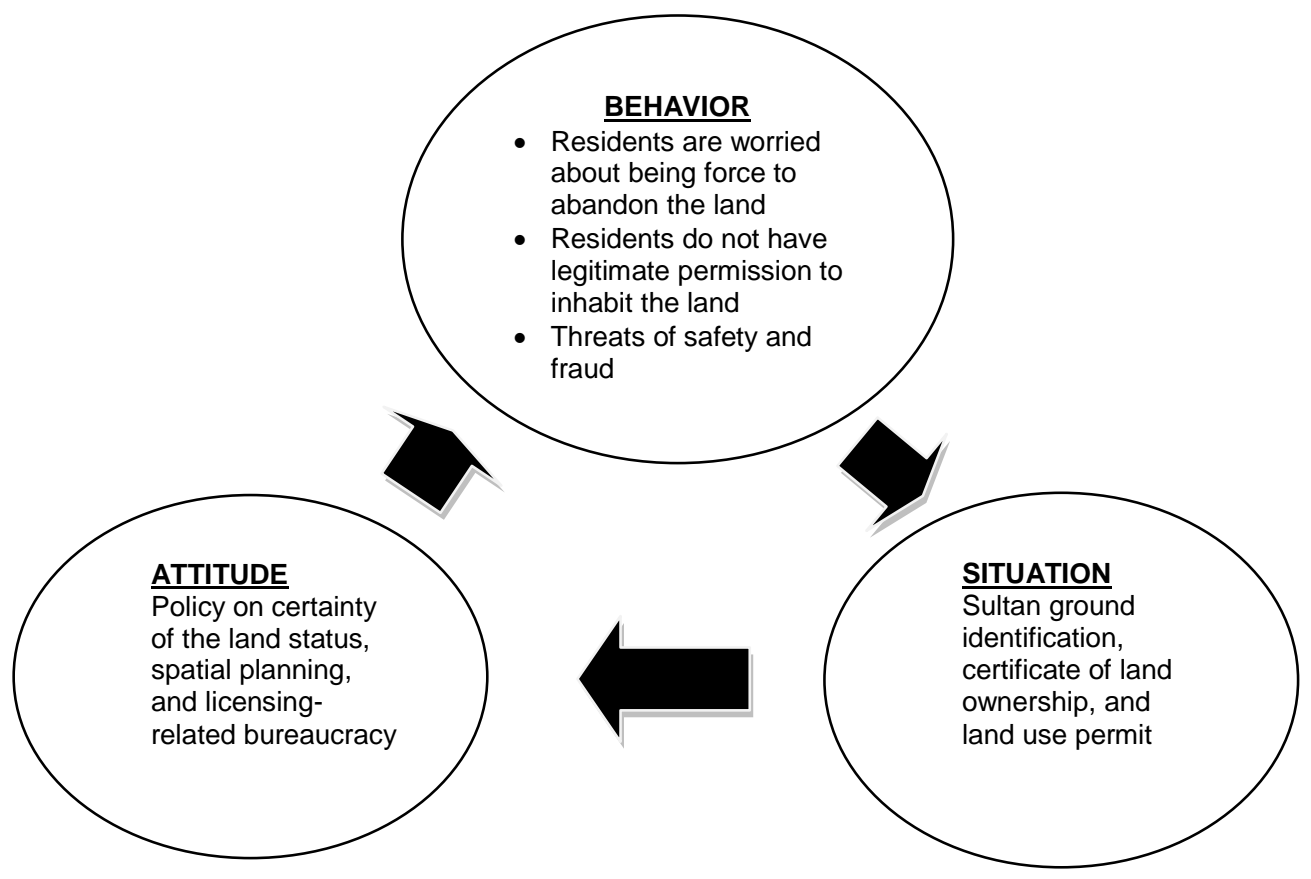

Figure 1 - Map of Residents' Conflicts

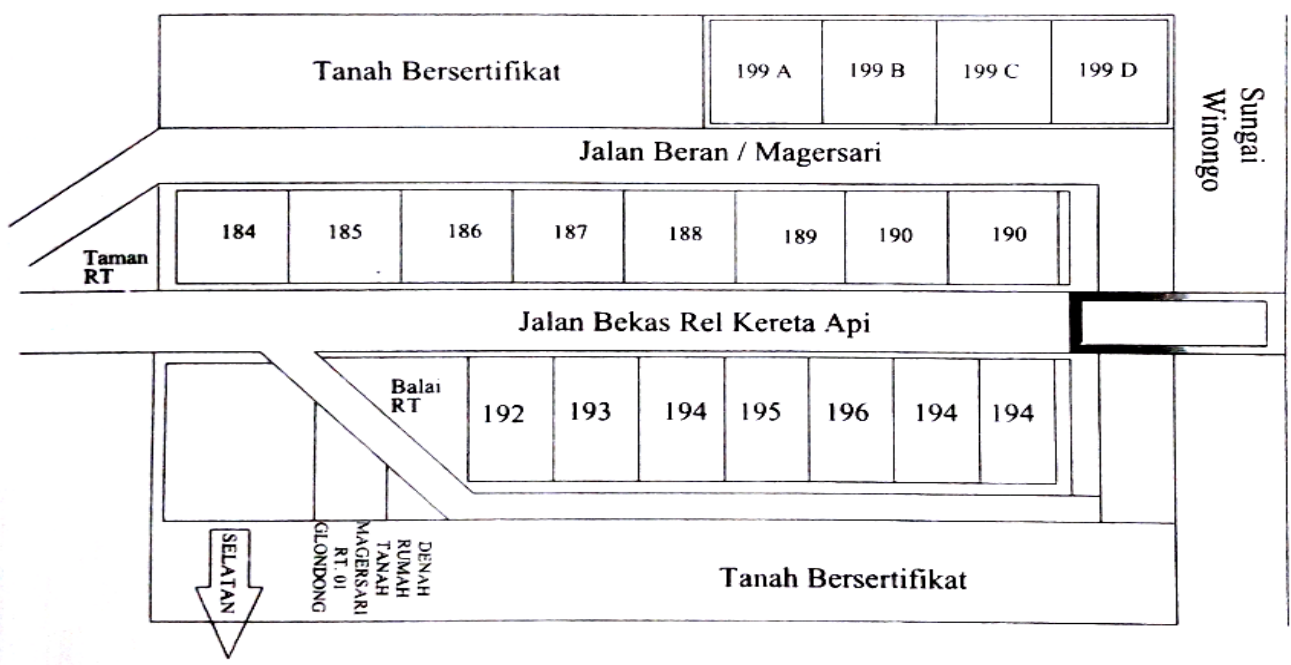

Fugure 2 - Map of Sultan Ground in Glondong Hamlet 
From the map of conflicts above, it can be formulated that there are 4 parties involved in this problem, they are residents, village officials, BPN, and Palace of Yogyakarta. Residents refer to those who inhabit the land; village officials refer to those in charge of spatial planning and public administration; BPN refers to a government body tasked with land affairs; and the Palace is the owner and controller of Sultan Ground land presently inhabited by residents.

After reading up on official documents in the form of land ownership certificates signed by the Palace and approved by the village head, it is revealed that the 927-square-meter land in Glondong Tirtonirmolo hamlet, Kasihan, Bantul, Yogykarkarta is registered in the name of the Sultanate of Ngayogyakarto Hadiningrat or the Palace of Yogyakarta (Sultan Ground). This land is demarked, namely by JI Pitoyo Rajiman in the north, Wedi Kengser in the east, railway lines in the south, and highways in the west.

Based on questionnaires distributed to residents as to land use, the research collected data as illustrated below:

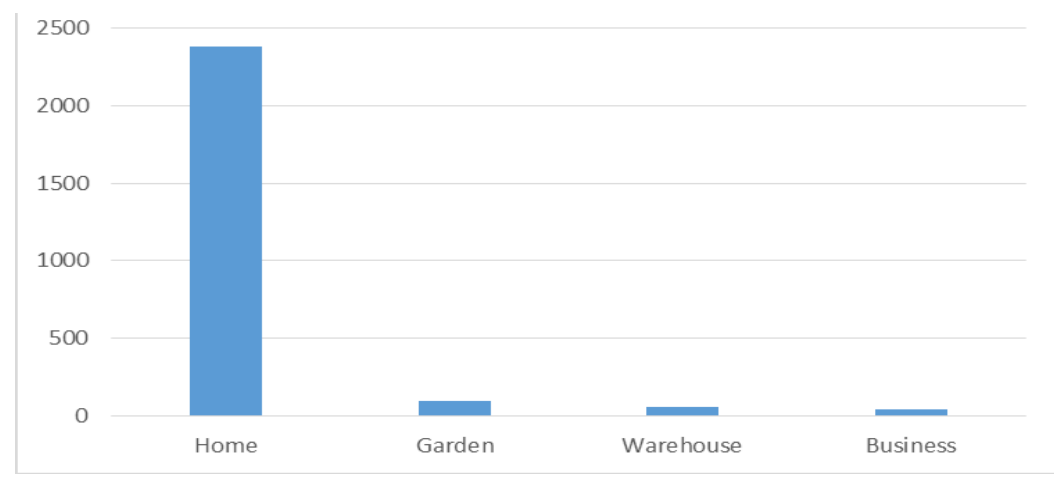

Figure 3 - Land use by residents

The figure above shows that most residents use the land occupied to build a house. The land means the world for them as it is the place where they live. The problema is they intend to obtain permission to inhabit the land. Inaccuracies in the area of land mentioned in the document and the one indicated in questionnaires resulted from different information provided by residents due to the absence of oficial data collection by either the government or BPN.

Table 1 - Conflict analysis

\begin{tabular}{|c|c|c|}
\hline Residents & $\begin{array}{l}\text { Individuals claiming as the heir of HB } \\
\text { VIII }\end{array}$ & Officials \\
\hline $\begin{array}{l}\text { Residents want to inhabit the land } \\
\text { because they do not have land to live in. } \\
\text { Residents want to get official permission } \\
\text { to inhabit the land. } \\
\text { Residents wish that they can avoid fraud } \\
\text { and intimidation. } \\
\text { Residents lack knowledge and } \\
\text { information about the law, rules, and } \\
\text { bureaucracy related to licensing } \\
\text { bureaucracy. }\end{array}$ & $\begin{array}{l}\text { Claiming themselves as legitimate heirs } \\
\text { of Sultan HB VII and owners of the land. } \\
\text { Intending to take possession of Sultan } \\
\text { Groung. } \\
\text { Asking a sum of money to anyone who } \\
\text { sith to obtain the permit to occupy the } \\
\text { land. }\end{array}$ & $\begin{array}{l}\text { Dividing the land into plots and } \\
\text { categories. } \\
\text { Charging a sum of money to residents } \\
\text { to buy the land. }\end{array}$ \\
\hline
\end{tabular}

The problem dated back to the time after the earthquake in Bantul District in 2006. As The earthquake claimed more than 5,000 lives and inflicted damage to houses and injuries and trauma to many. Residents of Glondong hamlet whose houses were devastated in the incident then built a temporary shelter in the former Winongo Station in Glondong Tirtonirmolo hamlet, Kasihan, Bantul, Yogyakarta. They argued that the land is not individual property and vacant, albeit knowing that the land belongs to the Palace (Sultan Ground) and to inhabit it they must have an official permit.

As time passes, problems arise, i.e. rumour has it that the government has divided the land into plots and one has to pay a sum of money to inhabit it. On top of it, there are also 
individuals claiming themselves as the heirs of Sultan Hamengkubuwono VII and asking a sum of money to residents who wish to live there. Some residents have paid a sum of money get permission, expecting to inhabit the land legally.

Table 2 - Conflict resolution stages

\begin{tabular}{|c|c|c|c|c|}
\hline & Stage & & Activity & Output \\
\hline \multirow{3}{*}{1} & \multirow{3}{*}{$\begin{array}{l}\text { Certainty as to the land } \\
\text { status }\end{array}$} & 1 & Reading up on the Palace's oficial documents & \multirow{3}{*}{$\begin{array}{l}\text { The oficial status, which is } \\
\text { legally evident and robust }\end{array}$} \\
\hline & & 2 & Reading up on BPN's oficial documents & \\
\hline & & 3 & $\begin{array}{l}\text { Reading up on the regional government's oficial } \\
\text { documents/notes }\end{array}$ & \\
\hline \multirow{3}{*}{2} & \multirow{3}{*}{$\begin{array}{l}\text { View of relevant } \\
\text { parties }\end{array}$} & 1 & $\begin{array}{l}\text { Reading up on the legally applicable rules on land affairs } \\
\text { established by BPN }\end{array}$ & \multirow{3}{*}{$\begin{array}{l}\text { Applicable regulation as to } \\
\text { permits to use land }\end{array}$} \\
\hline & & 2 & $\begin{array}{l}\text { Reading up on the legally applicable rules on SG } \\
\text { established by the Palace }\end{array}$ & \\
\hline & & 3 & $\begin{array}{l}\text { Reading up on legally applicable policy and agreement on } \\
\text { spacial planning established by the regional government }\end{array}$ & \\
\hline \multirow{4}{*}{3} & \multirow{4}{*}{ Implementation } & 1 & Dissemination of information to residents & \multirow{4}{*}{$\begin{array}{l}\text { Complete application } \\
\text { documents }\end{array}$} \\
\hline & & 2 & Data collection on SG right holders & \\
\hline & & 2 & Land demarking & \\
\hline & & 3 & Submission of complete documents & \\
\hline \multirow{3}{*}{4} & \multirow{3}{*}{ Application } & 1 & Official statement of the village oficial as to the land & \multirow{3}{*}{ Application submission } \\
\hline & & 2 & Submission of documents to the Palace & \\
\hline & & 3 & Registration at BPN & \\
\hline \multirow{2}{*}{5} & \multirow{2}{*}{ Assistance } & 1 & Establishment of a joint association & \multirow{2}{*}{$\begin{array}{l}\text { The residents' association } \\
\text { and teamwork }\end{array}$} \\
\hline & & 2 & Verification and validation & \\
\hline
\end{tabular}

\section{RESULTS AND DISCUSSION}

The permit to use Sultan Ground known as surat kekancingan is necessary for any residents who intend to use it. It constitutes a valid proof stipulating an agreement between the Palace and the resident as the holder of the right over such land. The following are provisions set out in surat kekancingan:

- The resident concerned is granted permission to temporarily use the land of Sri Sultan Hamengku Buwono of the Palace of Yogyakarta;

- The resident concerned is entitled to use magersari land to manage and exploit on his/her own interests and shall be solely responsable for any consequences (e.g. losses) or liabilities relating to it;

- The resident concerned shall use the land for residential purposes only and are not allowed to use it for other purposes that may do the other party harm, such as selling the land;

- The resident concerned may build a building or house used to run a business;

- The resident concerned is required to maintain the land in the same good conditions, and complies with the law;

- The resident concerned shall not transfer the right to use the land to another party;

- Land use for a particular period of time is set out in an agreement;

- The subsequent holder of the right to such land shall be entitled to the remaining term of the agreement and may have it extended;

- The transferee shall pay tributary;

- The tributary shall be paid to the Palace of Yogyakarta's Panitikismo office;

- In the event of termination of the agreement, the resident concerned shall hand over the land to the Palace in the same good conditions and shall not ask for damages in exchange of the building he/she has built;

- Violation committed by the resident concerned shall result in cancellation of the agreement and the land shall automatically be handed over to the Sultanate.

The following are primary requirements to obtain surat kekancingan: the applicant is an Indonesian national and submits an application to Panitikismo office. If his/her application is approved, the applicant will be granted surat kekancingan and register it at BPN. 


\section{CONCLUSION}

Any residents who intend to inhabit Sultan Ground are required to comply with the legally applicable rules established by the Palace of Yogyakarta and BPN. They may apply for a permit to use such land, i.e. Surat Kekancingan, by submitting an application to the Palace's Panitikismo, followed by registration at BPN. Such an application must be approved by the regional government as evidenced by the issuance of a certificate. These residents need to build a community or association in order to facilitate the application, avoid a fraud, and get assistance.

\section{ACKNOWLEDGEMENTS}

The authors would like to thank the Ministry of Research, Technology, and Higher Education of the Republic of Indonesia for facilitating this research through the PTUPT Research Scheme and providing financial support to produce this publication

\section{REFERENCES}

1. Loo, C. (2014) 'The Role of Community Participation in Climate Change Assessment and Research', Journal of Agricultural and Environmental Ethics, 27(1), pp. 65-85. doi: 10.1007/s10806-013-9452-0.

2. Marcus, R., Wilkinson, J. and Marshall, J. (2002) 'Poverty Reduction Strategy Papers (PRSPS)--Fulfilling Their Potential for Children in Poverty?', Journal of International Development, 14(8), pp. 1117-1128. doi: 10.1002/jid.953.

3. Mohindra, K. S., Narayana, D. and Haddad, S. (2010) "My story is like a goat tied to a hook." Views from a marginalised tribal group in Kerala (India) on the consequences of falling ill: A participatory poverty and health assessment', Journal of Epidemiology and Community Health, 64(6), pp. 488-494. doi: 10.1136/jech.2008.086249.

4. Muhsin, A., Hapsoro, D. S. and Yuni, S. (2018) 'Community-Based Poverty Alleviation Using Rural Appraisal', Russian Journal of Agricultural and Socio-Economic Sciences, 6(June). doi: 10.1093/gigascience/giy047/4982941.

5. Muhsin, A., Nafisah, L. and Siswanti, Y. (2018) Participatory Rural Appraisal (PRA) For Corporate Social Responsibility (CSR). 1st edn. Edited by N. F. Subekti. Yogyakarta: Deepublish. Available at: www.deepublish.co.id.

6. Nafisah, L., Muhsin, A. and Siswanti, Y. (2019) 'Development of citizen advocacy model using a participatory approach', Russian Journal of Agricultural and Socio-Economic Sciences, 1(January), pp. 412-419. doi: 10.18551/rjoas.2019-01.50.

7. Najman, J. M. et al. (2010) 'Family poverty over the early life course and recurrent adolescent and young adult anxiety and depression: A longitudinal study', American Journal of Public Health, 100(9), pp. 1719-1723. doi: 10.2105/AJPH.2009.180943.

8. Najman, J. M. et al. (2018) 'The inter- and intra- generational transmission of family poverty and hardship (adversity): A prospective 30 year study', PLoS ONE, 13(1), pp. 113. doi: 10.1371/journal.pone.0190504.

9. Schulz, A. J. et al. (2012) 'Associations between socioeconomic status and allostatic load: Effects of neighborhood poverty and tests of mediating pathways', American Journal of Public Health, 102(9), pp. 1706-1714. doi: 10.2105/AJPH.2011.300412.

10. Thomas, T. et al. (2012) 'Design of a Community Ownership and Preparedness Index: using data to inform the capacity development of community-based groups', Journal of Epidemiology and Community Health, 66(Suppl 2), pp. ii26-ii33. doi: 10.1136/jech-2011200590. 